\title{
EPSTEIN-BARR VIRUS - MOLECULAR BASIS FOR MALIGNANT TRANSFORMATION
}

\author{
Tsvetelina Popova ${ }^{1}$, Tatina Todorova ${ }^{2}$, Gabriela Tsankova ${ }^{2}$, Lilia Ivanova ${ }^{3}$, Todor Raykov ${ }^{4}$, \\ Neli Ermenlieva ${ }^{1}$, Emilia Georgieva ${ }^{1}$ \\ ${ }^{1}$ TRS "Medical laboratory assistant" Medical College, Medical University of Varna \\ ${ }^{2}$ Department of Preclinical and Clinical Sciences, Medical University of Varna \\ ${ }^{3}$ Department of Microbiology and Virology, Medical University of Varna \\ ${ }^{4}$ Association of Patients with Rheumatoid Arthritis
}

\begin{abstract}
Epstein-Barr (EBV) is a widespread virus which can be detected in more than $\mathbf{9 0 \%}$ of world population. Primary EBV infection during adolescence and adulthood results in infectious mononucleosis, while in children it is usually asymptomatic. EBV is responsible for different malignant forms of B-cell or epithelial cancers, such as Hodgkin's and non-Hodgkin's lymphoma, Burkitt's lymphoma, post-transplant lymphoproliferative disorders, nasopharyngeal carcinoma, hairy leukoplakia and HIV-associated lymphomas. Evidence exists that an infection with EBV is also linked with a higher risk of hepatocellular and gastric cancers, as well as autoimmune diseases.

EBV shows two alternative life cycles - latent and lytic. After the primary infection, the virus remains in the B lymphocytes in latency, while the lytic infection takes place predominantly in the epithelial cells and can last for months with constant virus release in saliva and nasopharyngeal secretion. Unlike other herpes viruses, the development of oncological diseases is linked with the latent cycle, as a result of the immune response failure to control latently infected cells.
\end{abstract}

With the present work we try to concisely review the current knowledge about mechanisms of EBV pathogenesis in humans and to summarize recent findings in the field.

Keywords: Epstein-Barr virus, EBV pathogenicity, EBV latency, malignant transformation

\section{INTRODUCTION}

EBV is a virus frequently found among the human population and transmitted mainly through saliva, blood transfusion or organ transplantation. Sexual transmission is also possible.

\footnotetext{
Address for correspondence:

Tatina T. Todorova

Department of Preclinical and Clinical Sciences

Faculty of Pharmacy

Medical University of Varna

3, Bregalniza Str., 9002 Varna, Bulgaria

e-mail:Tatina.Todorova@mu-varna.bg
}

Received: December 15, 2015

Accepted: February 9, 2016
It is a complex, spherical virus with a size between 120 and $180 \mathrm{~nm}$. Principal structural elements of EBV include: (1) double-strand DNA nucleoid; (2) icosahedral capsid formed from 162 capsomeres; (3) lipoprotein envelope containing viral glycoproteins; and (4) tegument, placed between the capsid and the envelope $(1,2)$. The genome of EBV is a linear double-strand DNA of $172 \mathrm{~kb}$ (for B-95-8 strain) or 184 $\mathrm{kb}$ (for other strains) (3) coding for 86 (4) or 100 viral proteins, respectively (3). These genes can be specific for Herpes viruses family, for Gammaherpesvirinae subfamily or for genus Lymphocryptovirus (5).

\section{EBV Malignant Transformation}

In early childhood, primary EBV infection is usually asymptomatic while in adolescence and 
adulthood it is present as infectious mononucleosis (6). EBV is the first known human tumor virus (7) with high transforming activity towards lymphoid cells. The virus has two „in vivo" target tissues - Blymphocytes and epithelial cells (8) with different corresponding mechanisms for adhesion and entry. The main receptor on B cells is CD21 (CR2 or complement receptor type 2) which interacts with the viral gp350/220 molecules, while still unknown receptor on epithelial cells is recognized by the $\mathrm{gH} / \mathrm{gL}$ viral protein (9). Another possible mechanism for epithelial cell infection is the detection of EBV BMRF2 protein from betha- 1 or alpha-5, betha-1 cellular integrins via IgA-mediated interaction (10-13). Some authors accept more efficient epithelial infection after preliminary adhesion of EBV to resting B-cells and consecutive transfer to the tolerant epithelium (14).

EBV shows two alternative life cycles - lytic and latent. The lytic infection takes place predomi- ed to the memory B-cells where it develops a latency program (19). Latently infected B-cells express only $10 \%$ of the EBV genome and rarely support the lytic life cycle of the virus $(6,20)$.

EBV persists in memory B-cells in latency program 0 suppressing the expression of all latent genes except for Epstein-Barr virus-encoded small RNAs (EBERs) and BamHI A rightward transcripts (BARTs) (17,21). The lack of viral genes expression helps the virus to escape the immune response of the host. Under Latency 0 program, EBNA1 (EBV protein found in EBV-related tumorigenesis) is only expressed during cell division. Latency program I involves a minimal level of gene expression needed for EBV genome persistence in the host cell (22). The different latency programs of EBV, together with the latent gene expression and the corresponding diseases, are presented in Table 1.

Table 1. Different latency programs of EBV and gene expression in EBV-associated diseases (according to (6))

\begin{tabular}{|c|c|c|c|c|c|c|c|}
\hline $\begin{array}{l}\text { Latency } \\
\text { program }\end{array}$ & EBNA-1 & EBNA-2 & EBNA-3 & LMP-1 & LMP-2 & EBER & Diseases \\
\hline I & + & - & - & - & - & + & Burkitt's lymphoma \\
\hline II & + & - & - & + & + & + & $\begin{array}{l}\text { Hodgkin's lymphoma, } \\
\text { nasopharyngeal } \\
\text { carcinoma, peripheral } \\
\text { T-cell lymphomas }\end{array}$ \\
\hline III & + & + & + & + & + & + & $\begin{array}{l}\text { Lymphoproliferative } \\
\text { disorders, X-linked } \\
\text { lymphoproliferative } \\
\text { disorders, HIV- } \\
\text { associated lymphomas }\end{array}$ \\
\hline other & $+/-$ & - & - & - & + & + & Healthy carriers \\
\hline
\end{tabular}

EBNA - EBV nuclear antigen, LMP - latent membrane protein, EBER - EBV-encoded small RNAs

nantly in the epithelial cells and can last for weeks or months with constant release of infectious viral particles in saliva and nasopharyngeal secretions $(15,16)$. The primary infection of naive B-cells in the oropharynx is the most effective and leads to their constant proliferation $(17,18)$, as the virus remains in the B-lymphocytes (latent infection) and its genome is located in the nucleus under the form of a circular episome. In immunocompetent individuals cytotoxic T cells (CTLs) and NK cells control the spread of EBV-infected B-lymphocytes and the virus is limit-
During the primary infection the infected B cells tend to spread rapidly and to infect other cells. The new infection is overcome by the cytotoxic Tlymphocytes and in immunocompetent individuals cells with lytic infection are rarely found (23). Despite the type of infection, EBV can persist in the cells to the end of the host's life. Reactivation is a way to infect new lymphocytes and spread virus particles. It occurs during the recirculation of EBV-infected Bcells in the lymphoid tissue. B-cells react to different physiological stimuli - lack of CD40 activation, B- 
Tsvetelina Popova, Tatina Todorova, Gabriela Tsankova et al.

cell receptor stimulation and LMP1 expression (2426). As a result, a viral replication of ZEBRA (which activates the switch from the latent to the lytic gene expression program) and VCA (viral capsid antigen) starts to release new virions (24).

Unlike other herpes viruses, the development of EBV-related oncogenic diseases is associated with the latent life cycle of the virus. EBV-related malignant diseases occur when the immune response fail to control the spread of latently infected cells. At least 5 genes are involved in the process of malignization by blocking tumor-suppression cell mechanisms (as is the case of other DNA tumor viruses). In general, EBV is less cancerogenic than the small oncogenic
A20 levels) (34,35). LMP1 functions as constitutively active receptor in the family of tumor necrosis factor receptors (TNFR) and activates cell signaling pathways via ligand-independent way by mimicking the active CD40 $(36,37)$. Its activity is associated with at least four cell-signaling pathways - NF-kB, JNK (AP1, p38 ), MAPK and JAK/STAT $(38,39)$. LMP1 stimulates cytokines production (IL-6, IL-8) via interaction with p38 mitogen-activated protein kinase pathway or NF- $\kappa \mathrm{B}$ signaling pathway in epithelial cells (40). Phosphatidylinositol 3-kinase (PI3-K) pathway could also be activated, leading to cell survival. The activity of LMP1 and other essential latent viral proteins is listed in Table 2.

Table 2. Essential latent proteins of EBV (according to (3)).

\begin{tabular}{|c|c|c|}
\hline Gene & Localization & Function \\
\hline EBNA-1 & Nuclear & $\begin{array}{l}\text { Latent phase viral DNA replication: binds the viral latent origin, oriP; } \\
\text { activates transcription of other latent genes }\end{array}$ \\
\hline EBNA-2 & Nuclear & $\begin{array}{l}\text { Transcriptional activator of viral and cellular genes: targeted at DNA } \\
\text { by the cellular J kappa recombination signal sequence binding protein } \\
\qquad(\mathrm{RBPJ})\end{array}$ \\
\hline LMP-1 & Plasma membrane & $\begin{array}{l}\text { Transcriptional activator: engages signaling proteins for the tumor ne- } \\
\text { crosis factor receptor family; cause B cell activation and differentiation; } \\
\text { prevents apoptosis }\end{array}$ \\
\hline EBNA-3C & Nuclear & Transcriptional activator of CD21, LMP1,fine control of EBNA2 \\
\hline EBNA-3A & Nuclear & $\begin{array}{c}\text { Contributes to the initiation of cellular proliferation in EBV infected B } \\
\text { cells }\end{array}$ \\
\hline
\end{tabular}

DNA viruses (27). Malignant transformation of EBV is in a combination with other factors, such as strong immune deficiency $(28,29)$. The time between the primary infection and the malignization depends on geographic and genetic factors (30-32).

During the primary infection, several EBV genes are expressed - some of the most important ones are EBNA-1 and LMP-1 (27,33). LMP-1 is a primary oncogene - transgenic mice expressing the corresponding protein soon develop lymphomas. The product of the gene is detected in most of the EBV-associated oncogenic diseases (Hodgkin's lymphoma, post-transplant lymphoproliferative disorders, nasopharyngeal carcinoma and HIV-associated lymphomas). Its expression causes changes related to B-cell activation, including B-cell fusion, augmentation of CD23, CD39, CD40, CD44 expression and anti-apoptotic effects (via increase in the BCL-2 and
The oncogenesis is multistep process and needs additional events at cellular level - higher telomerase regulation, suppression of cell anti-oncogenic proteins such as pRb, p53 and others.

In $80 \%$ of cases of Burkitt's lymphoma, a chromosomal translocation (t8:14) in the long arm c-myc region is found. This leads to overexpression of cmyc and uncontrolled proliferation of B-lymphocytes. Another factor in this process is the loss of host immune control - a fact that explains the linkage between lymphoma and malaria (27).

Geographic and genetic factors play important role in the pathogenicity of nasopharyngeal carcinoma (NPC), too. There is a positive association between NPC and HLA alleles A2, B14 and B46, responsible for chromosomal aberrations-t(1:3) and gene polymorphism (41-43). 
The main reason for post-transplant lymphoproliferative disorders (PTLD) is the impossibility of CTL to control EBV infected B-lymphocytes (6) resulting in their uncontrolled spread and proliferation.

\section{CONCLUSIONS}

The wide presence of EBV and its association with several diseases explains its high social importance. Studying EBV pathogenesis helps understand the disease genesis and will help future therapeutics and prevention.

\section{REFERENCES}

1. Dolyniuk M, Pritchett R, Kieff E. Proteins of Epstein-Barr virus. I. Analysis of the polypeptides of purified enveloped Epstein-Barr virus. J Virol. 1976 Mar;17(3):935-49.

2. Dolyniuk M, Wolff E, Kieff E. Proteins of EpsteinBarr Virus. II. Electrophoretic analysis of the polypeptides of the nucleocapsid and the glucosamineand polysaccharide-containing components of enveloped virus. J Virol. 1976 Apr;18(1):289-97.

3. Kieff E, Rickinson AB. Epstein -Barr virus and its replication. In: Fields Virology. 2007. p. Fields Virology.

4. Tarbouriech N, Buisson M, Géoui T, Daenke S, Cusack S, Burmeister WP. Structural genomics of the Epstein-Barr virus. Acta Crystallogr D Biol Crystallogr. 2006 Oct;62(Pt 10):1276-85.

5. Baer R, Bankier AT, Biggin MD, Deininger PL, Farrell PJ, Gibson TJ, et al. DNA sequence and expression of the B95-8 Epstein-Barr virus genome. Nature. Jan;310(5974):207-11.

6. Cohen JI. Epstein-Barr virus infection. N Engl J Med. 2000 Aug 17;343(7):481-92.

7. Epstein MA. Recent studies with EB virus. Yale J Biol Med. 1975 Nov;48(5):431-7.

8. Li QX, Young LS, Niedobitek G, Dawson CW, Birkenbach M, Wang F, et al. Epstein-Barr virus infection and replication in a human epithelial cell system. Nature. 1992 Mar 26;356(6367):347-50.

9. Molesworth SJ, Lake CM, Borza CM, Turk SM, Hutt-Fletcher LM. Epstein-Barr virus gH is essential for penetration of $B$ cells but also plays a role in attachment of virus to epithelial cells. J Virol. 2000 Jul;74(14):6324-32.

10. Tugizov SM, Berline JW, Palefsky JM. EpsteinBarr virus infection of polarized tongue and na- sopharyngeal epithelial cells. Nat Med. 2003 Feb 18;9(3):307-14.

11. Xiao J, Palefsky JM, Herrera R, Tugizov SM. Characterization of the Epstein-Barr virus glycoprotein BMRF-2. Virology. 2007 Mar 15;359(2):382-96.

12. Gan YJ, Chodosh J, Morgan A, Sixbey JW. Epithelial cell polarization is a determinant in the infectious outcome of immunoglobulin A-mediated entry by Epstein-Barr virus. J Virol. 1997 Jan;71(1):519-26.

13. Sixbey JW, Yao QY. Immunoglobulin A-induced shift of Epstein-Barr virus tissue tropism. Science. 1992 Mar 20;255(5051):1578-80.

14. Shannon-Lowe CD, Neuhierl B, Baldwin G, Rickinson AB, Delecluse H-J. Resting B cells as a transfer vehicle for Epstein-Barr virus infection of epithelial cells. Proc Natl Acad Sci U S A. 2006 May 2;103(18):7065-70.

15. Näher $H$, Petzoldt $D$. [Epstein-Barr virus infection-a lympho- and epitheliotropic infection]. Hautarzt. 1992 Mar;43(3):114-9.

16. Niedobitek G, Young LS. Epstein-Barr virus persistence and virus-associated tumours. Lancet (London, England). 1994 Feb 5;343(8893):333-5.

17. Babcock GJ, Decker LL, Volk M, Thorley-Lawson DA. EBV persistence in memory B cells in vivo. Immunity. 1998 Sep;9(3):395-404.

18. Thorley-Lawson DA, Gross A. Persistence of the Epstein-Barr virus and the origins of associated lymphomas. N Engl J Med. 2004 Mar 25;350(13):1328-37.

19. Heslop HE, Ng CY, Li C, Smith CA, Loftin SK, Krance RA, et al. Long-term restoration of immunity against Epstein-Barr virus infection by adoptive transfer of gene-modified virus-specific $\mathrm{T}$ lymphocytes. Nat Med. 1996 May;2(5):551-5.

20. Qu L, Green M, Webber S, Reyes J, Ellis D, Rowe D. Epstein Barr Virus Gene Expression in the Peripheral Blood of Transplant Recipients with Persistent Circulating Virus Loads. J Infect Dis. 2000 Oct 1;182(4):1013-21.

21. Babcock GJ, Decker LL, Freeman RB, Thorley-Lawson DA. Epstein-barr virus-infected resting memory B cells, not proliferating lymphoblasts, accumulate in the peripheral blood of immunosuppressed patients. J Exp Med. 1999 Aug 16;190(4):567-76.

22. Rowe M, Lear AL, Croom-Carter D, Davies AH, Rickinson AB. Three pathways of Epstein-Barr vi- 
Tsvetelina Popova, Tatina Todorova, Gabriela Tsankova et al.

rus gene activation from EBNA1-positive latency in B lymphocytes. J Virol. 1992 Jan;66(1):122-31.

23. Tailleux L, Neyrolles O, Honore-Bouakline S, Perret E, Sanchez F, Abastado J-P, et al. Constrained Intracellular Survival of Mycobacterium tuberculosis in Human Dendritic Cells. J Immunol. American Association of Immunologists; 2003 Feb 15;170(4):1939-48.

24. Thorley-Lawson DA. Epstein-Barr virus: exploiting the immune system. Nat Rev Immunol. 2001 Oct;1(1):75-82.

25. Tovey MG, Lenoir G, Begon-Lours J. Activation of latent Epstein-Barr virus by antibody to human IgM. Nature. 1978 Nov 16;276(5685):270-2.

26. Adler B, Schaadt E, Kempkes B, Zimber-Strobl U, Baier B, Bornkamm GW. Control of Epstein-Barr virus reactivation by activated CD40 and viral latent membrane protein 1. Proc Natl Acad Sci U S A. 2002 Jan 8;99(1):437-42.

27. Nathanson N. Viral Pathogenesis and Immunity. Academic Press; 2007. 280 p.

28. Knowles DM. Immunodeficiency-associated lymphoproliferative disorders. Mod Pathol. 1999 Feb;12(2):200-17.

29. Loren AW, Porter DL, Stadtmauer EA, Tsai DE. Post-transplant lymphoproliferative disorder: a review. Bone Marrow Transplant. 2003 Feb;31(3):145-55.

30. Raab-Traub N. Epstein-Barr virus in the pathogenesis of NPC. Semin Cancer Biol. 2002 Dec;12(6):431-41.

31. Hsu JL, Glaser SL. Epstein-barr virus-associated malignancies: epidemiologic patterns and etiologic implications. Crit Rev Oncol Hematol. 2000 Apr;34(1):27-53.

32. Yu MC, Yuan J-M. Epidemiology of nasopharyngeal carcinoma. Semin Cancer Biol. 2002 Dec;12(6):421-9.

33. Rowe M, Khanna R, Jacob CA, Argaet V, Kelly A, Powis S, et al. Restoration of endogenous antigen processing in Burkitt's lymphoma cells by EpsteinBarr virus latent membrane protein-1: coordinate up-regulation of peptide transporters and HLAclass I antigen expression. Eur J Immunol. 1995 May;25(5):1374-84.

34. Kulwichit W, Edwards RH, Davenport EM, Baskar JF, Godfrey V, Raab-Traub N. Expression of the Epstein-Barr virus latent membrane protein 1 induc- es B cell lymphoma in transgenic mice. Proc Natl Acad Sci U S A. 1998 Sep 29;95(20):11963-8.

35. Laherty CD, Hu HM, Opipari AW, Wang F, Dixit VM. The Epstein-Barr virus LMP1 gene product induces A20 zinc finger protein expression by activating nuclear factor kappa B. J Biol Chem. 1992 Dec 5;267(34):24157-60.

36. Gires O, Zimber-Strobl U, Gonnella R, Ueffing M, Marschall G, Zeidler R, et al. Latent membrane protein 1 of Epstein-Barr virus mimics a constitutively active receptor molecule. EMBO J. 1997 Oct 15;16(20):6131-40.

37. Kilger E, Kieser A, Baumann M, Hammerschmidt W. Epstein-Barr virus-mediated B-cell proliferation is dependent upon latent membrane protein 1 , which simulates an activated CD40 receptor. EMBO J. 1998 Mar 16;17(6):1700-9.

38. Huen DS, Henderson SA, Croom-Carter D, Rowe $M$. The Epstein-Barr virus latent membrane protein-1 (LMP1) mediates activation of NF-kappa B and cell surface phenotype via two effector regions in its carboxy-terminal cytoplasmic domain. Oncogene. 1995 Feb 2;10(3):549-60.

39. Floettmann JE, Eliopoulos AG, Jones M, Young LS, Rowe M. Epstein-Barr virus latent membrane protein-1 (LMP1) signalling is distinct from CD40 and involves physical cooperation of its two C-terminus functional regions. Oncogene. $1998 \mathrm{Nov}$ 5;17(18):2383-92.

40. Eliopoulos AG, Gallagher NJ, Blake SM, Dawson CW, Young LS. Activation of the p38 mitogen-activated protein kinase pathway by Epstein-Barr virus-encoded latent membrane protein 1 coregulates interleukin- 6 and interleukin- 8 production. J Biol Chem. 1999 Jun 4;274(23):16085-96.

41. Goldsmith DB, West TM, Morton R. HLA associations with nasopharyngeal carcinoma in Southern Chinese: a meta-analysis. Clin Otolaryngol Allied Sci. 2002 Feb;27(1):61-7.

42. Xiong W, Zeng ZY, Xia JH, Xia K, Shen SR, Li XL, et al. A susceptibility locus at chromosome 3 p21 linked to familial nasopharyngeal carcinoma. Cancer Res. 2004 Mar 15;64(6):1972-4.

43. Feng B-J, Huang W, Shugart YY, Lee MK, Zhang F, Xia J-C, et al. Genome-wide scan for familial nasopharyngeal carcinoma reveals evidence of linkage to chromosome 4. Nat Genet. 2002 Aug;31(4):395-9. 